\title{
Transformation of Public Research Institutes' Role in Indonesia: The Case of Indonesian Institute of Sciences (LIPI) and the Agency for the Assessment and Application of Technology (BPPT)
}

\author{
Indah Purwanigsih ${ }^{\mathrm{a}}$, Kusdi ${ }^{\mathrm{b}}$, Fadhillah Amin $^{\mathrm{c}}$ \\ ${ }_{a, b, c}$ Brawijaya University, Malang, Jawa Timur, Indonesia
}

\section{ARTICLE INFORMATION}

Article history:

Date submission: 03 October 2017

First revision: 24 October 2017

Accepted: 15 November 2017

Available online: 28 November 2017

Keywords: transformational role, $S \& T$ development strategy, public research institute

\section{ABSTRACT}

The government of Indonesia has a changing strategy for Science and Technology (S\&T) development. This condition has influenced institutional development, which in turn may have affected the transformational role of public research institutes. This study attempts to investigate the trajectory of Indonesian S\&T development strategy from the colonial era through the Old Older, the New Order, and following the Asian Financial Crisis. In response to this changing of development strategy, it eventually analyzes how the role of public research institutes has transformed, by takings LIPI and BPPT as case studies. This study employs a historical approach by using interview and document analysis to investigate the trajectory of S\&T development in Indonesia and the transformation of LIPI's and BPPT's role. The findings suggest that political transformation has much affected the government's strategy on Indonesian S\&T development. Moreover, LIPI and BPPT tend to transform their role following the government's strategy by considering either demand from society and industry or their strong point of early inception.

\section{INTISARI}

Pemerintah telah menerapkan beberapa strategi yang berbeda di setiap periode dalam pengembangan ilmu pengetahuan dan teknologi (iptek) di Indonesia. Perubahan strategi pengembangan iptek ini berpengaruh terhadap kelembagaan riset, yang pada akhirnya berdampak pada perubahan peran lembaga riset pemerintah. Penelitian ini mengakaji perubahan strategi pengembangan iptek di Indonesia mulai dari masa penjajahan, Orde Lama, Orde Baru, dan setelah krisis ekonomi Asia tahun 1997. Perubahan peran lembaga riset pemerintah sebagai akibat dari perubahan strategi pengembangan riset selanjutnya dianalisis dengan mengkaji peran LIPI dan BPPT sebagai studi kasus. Penelitian dilakukan dengan pendekatan sejarah melalui interview dan analisis dokumen. Hasil penelitian menunjukkan bahwa perubahan kebijakan iptek di Indonesia lebih banyak dipengaruhi oleh dinamika politik. Sedangkan perubahan peran LIPI dan BPPT lebih ditujukan untuk mengikuti strategi pemerintah daripada menjawab kebutuhan masyarakat dan industry, ataupun memperhatikan potensi utama awal pembentukan lembaga.

2016 FIA UB. All rights reserved. 


\section{Introduction}

There is a growing debate among scholars over the development of science and technology (S\&T) in Indonesia. S\&T has been one of the policy instruments used to achieve national development goals, including sustainable economy and social welfare. Nevertheless, critics have observed that it has made few contributions to Indonesian industrial technology or economic development (OECD, 2013). Most of the research outputs end in reports, publications, and prototypes, whereas there are few results of public Research and Development $(R \& D)$ that have been further developed and utilized for industrial and technological capacity development, especially by private sectors (Bimantara, 2015). According to the Global Competitiveness Index, the capacity of Indonesian industry in terms of technology and innovation is limited. In 2013, Indonesia's innovation capacity ranked 24th out of 144 countries and fell to 30th in 2015.

Looking deeper into this issue, Indonesia is also recognized as one of the lower standard countries of research and development. Its expenditure for R\&D is lower than that of some emerging countries, including India, Malaysia and Thailand. In 2013, Indonesia's gross R\&D expenditure was around $0.08 \%$ of its national GDP. The government contributed around $74 \%$ of this gross R\&D expenditure. Public research institutes (PRIs) conduct most of the R\&D activities. On the other hand, the proportion of the budget for the R\&D program is smaller than that for routine funding, including salary of the institute's employees. The Indonesian Institute of Sciences (LIPI), the biggest PRI in Indonesia, spent around $40.5 \%$ of its budget for R\&D and supporting programs in the 2012-2015 period, while the Agency for the Assessment and Application of Technology (BPPT) spent around $41.3 \%$ at the same time.

However, between the 1970s and the 1990s, the socalled New Order period, Indonesia experienced a massive development of S\&T institution. This authoritarian state invested a large amount not only in $\mathrm{R} \& \mathrm{D}$, but also in industrial technology development (Amir, 2013). They also consider the importance of technology transfer for industry by establishing strategic state-owned companies.

Yet, there has been a significant change after the Asian Financial Crisis in 1997. The Asian crisis that initially hit the financial sector also affected the socio- political segment of the country. It was followed by the downturn of the New Order regime, resulting in reformation. Reformation has brought a big transformation to the country and to the S\&Tinstitution.

Therefore, this paper aims to investigate the trajectory of S\&T development strategy in Indonesia across different historical periods. The politico-economic dynamism of the country may have influenced the institutional transformation of Indonesian S\&T. This transformation would in turn affect the role of PRIs as the main actors of Indonesian S\&T development. This study focuses on LIPI and BPPT to demonstrate the transformational role of PRIs in Indonesia.

\section{Theory}

PRIs play an important role in the S\&T development of a country. They are also an integral part of the national innovation system. They fill the gap between basic research and development (Intarakumnerd \& Goto, 2016). The process of creation, development, and diffusion of S\&T conducted by PRIs can not only increase the stock of knowledge, but also improve firms' technological capacity and produce spillovers to industrial development (Coccia, 2012; Salter \& Martin, 2001).

PRIs would perform their role differently, depending on the system. Each system of innovation has different characteristics. An innovation system is not a narrow organization, which focuses solely on $R \& D$. It is embedded in a wider system of social economy, influenced by political and cultural dimensions for the determination of the policy direction of innovative activities (Ludvall, 1992 as cited in Edquist, 2004). Hence, the governments need to understand the condition and institutional framework of the country to find the best strategy for developing a good system. They have to consider some global aspects, including contemporary technological, institutional, and economic dynamics. The behavior and needs of the relevant agents are also important. Lastly, the specific context in which the process of catching up takes place should be considered, as well as other factors that can influence the innovation process (Freeman \& Louca, 2001 as cited in Edquist, 2004).

Moreover, the role of PRIs might change following rapid technological change, the demands of global competition, and change in the country's demands (Intarakumnerd \& Goto, 2016). A PRI's roles might include producing and transferring knowledge to firms. They could also become an "intermediary" in linking various stakeholders within the innovation system, including policy makers, technology producers, and firms as the user of technology.

\section{Research Method}

This paper employed historical approach through indepth interview with $\mathrm{S} \& \mathrm{~T}$ institutions related government officials and documents analysis in order to investigate the trajectory of Indonesian S\&T development strategy from the colonial era through the 
Old Older, the New Order, and following the Asian Financial Crisis. In response to this changing of development strategy, it eventually analyzes how the role of public research institutes has transformed, by taking LIPI and BPPT as case studies.

\section{Result and Discussion}

\subsection{Trajectory of $S \& T$ development in Indonesia}

The development of Indonesian research culture dates back to the colonial period several centuries ago. A long history of colonialism and imperialism impacted the formation of the state as well as the political and socioeconomic structures of the country in various ways (Reid, 2013). Another impact of colonialism was the flourishing of scientific research, which began during the occupation by Verenigde Oost-Indische Compagnie (VOC, Dutch East India Company) and continued by the Dutch colonial state (Boomgaard, 2006).

A work by Rumphius, a German naturalist in Dutch service in the $17^{\text {th }}$ century, records the rise of scientific research in Indonesia. He investigated the biodiversity of Indonesia and made a valuable discovery on the potentials of several plants and animals for medical use for human beings (Boomgaard, 2006). Medical research developed continuously, as tropical disease became epidemics following the increased intensity of European colonial expansion, particularly in Indonesia (Netherlands East Indies) under the Dutch (Boomgaard, 1993).

The research institution developed along with scientific research in the Netherlands East Indies. In 1817, the colonial government established's lands Plantentuin te Buitenzorg (National Botanical Garden in Bogor) as the first research institute of the country. It initially aimed to conduct agricultural research to cultivate potentially economic plantations from the archipelago for commercial use. However, the abundant natural resources eventually attracted scientists' interest to conduct more research of a scientific order (Pyenson, 1989).

The scientists attempted to negotiate the colonial government to establish an academy of science. Jacob Christian Koningsberger, a Dutch zoologist also the director of the National Botanical Garden, offered a proposal in 1913 in an attempt to explain the importance of a science council to supply scientific information for the government and to confer scientific distinction on select individuals. Finally, after preparing the inception of the institute in 1918, the colonial government founded Natuurwetenschappelijk Raad voor Nederlandsch Indie (the Netherlands Indies Scientific Congress) in 1928. This institute employed not only colonial scientists, but also pribumi (local) scientists (Pyenson, 1989).
After Indonesia gained independence in 1945, the Old Order (1945-1966) regime did not pay much attention to the development of scientific research. It was still occupied with new government's consolidation during this reconstruction era. The newly independent country was still trying to create a political structure for statebuilding in the coming years. A long history of oppressive colonialism led the Independent Indonesia to come up with a different political structure from the colonial power structure. The new government also attempted to build a nationalist spirit by nationalizing colonial companies and establishing indigenous institutions (Ricklefs, et.al, 2010). It was about to create a new identity. Despite that, there was no significant development in S\&T. The Old Order regime laid a strong foundation for S\&T development. It established Council for Science of Indonesia (MIPI) after abolishing the colonial research institutes. This strategy was not merely about creating indigenous institutions, but also providing an institutional basis for research activity in Indonesia to provide the government with scientific advice.

Indonesia experienced a great leap in S\&T development in the New Order era (1966-1998). The main characteristic of this regime was the pivotal role of the State and the use of military power in all matters. Institution and order became the measure of legitimacy, leaving little room for public and subordinate participation. Successfully recovered from the economic turbulence of the 1960s, the country experienced a rapid economic growth in the 1970s (Hill, 1994). After relying on an agriculture-based economy in the 1970s and enjoying the oil boom in early 1970s, the government wanted to increase the development of high technology following the success of newly industrialized Asian countries.

It was in 1974 that the two interests met. President Soeharto, who was interested in high technology as a means of accomplishing development goals, needed someone to realize his ambition. At the same time, B.J. Habibie, a Germany-educated aircraft engineer and later the third President of Indonesia, had long dreamed of building aircraft in his home country. With help from Soetowo, the director of Pertamina, Soeharto convinced Habibie to "bring reforms and changes in S\&T" for national development (Amir, 2013). He stressed the importance of having technology and skilled people over exploiting the abundant natural resources of the country for national development. Furthermore, because the aircraft industry needed a large amount of capital, especially to cover Habibie's engineering team from Germany, Pertamina, the largest and only state-owned oil company, would govern the funding of this enterprise (Amir, 2013).

Habibie had a great influence on Indonesian technological development plan. He introduced to 
rename the institution governing S\&T development. The Ministry of Research was renamed as Ministry of Research and Technology (Ristek) when Habibie joined the cabinet in 1979. It seemed like a simple change, but it had a great impact in the following years. Habibie insisted on the development of highly indigenous technology as well as on high quality human resources to build a competitive advantage for the future Indonesian economy. His agenda was that Indonesia should have local capacity to assess and to apply technology to minimize dependency on imported technology (Amir, 2008; Hill, 1997).

Habibie introduced a new technological development strategy - namely, "starting from the end, ending at the start. It started with adopting the existing technology to create added-value products. Developing new technology based on the existing ones was the next step, which was followed by developing new technology. The whole process culminated in conducting basic research for producing new knowledge (Rice, 1998).

The government employed some policy instruments for S\&T development in this era that completely reflected the authoritarian power. First, the government set the research agenda by prioritizing technological development. The DRN had identified several research areas for their potential contribution to national development: biotechnology, medical technology, food technology, product and production engineering, material science, chemistry and process engineering, energy technology, electronics and informatics, and environmental protection technologies (Samadikun, 1998). All areas were included in the form of technological development that reflected the intention of the State to develop high technology. However, the most attention was given to the aircraft industry.

Second, Habibie, as the closest man to Soeharto, played a key role in structuring the industrial technology policy in all sectors, particularly in governmental departments and state-owned enterprises. He had become a cabinet member since the third Development Cabinet (1979-1984). He had headed Ministry of Research and Technology (Ristek) for almost 20 years, being at the same time the chairperson of BPPT and the Managing Agency for Strategic Industries (BPIS) simultaneously. He was the first influential cabinet member coming from neither a strong economic background nor from a powerful ministry, such as the Ministry of National Development Planning (Bappenas). Bappenas was initially the institution responsible for preparing all programs and budgets for the development plan (Sato, 2017).

These three institutions were considered to be the favored agents of the authoritarian technological state. BPPT was the policy arm of Ristek. It prepared the industrial technology policy and determined its implementation on state-owned strategic industries, which were managed under BPIS. BPIS organized ten state-owned companies to produce high technology products, including the aircraft industry, the shipbuilding and maritime industry, the land transportation industry, the electronics and telecommunication industry, the energy industry, the engineering and agriculture industry, and the defense and security industry (Pitono, 1996; Amir, 2013). The collaboration between these institutions formed a circle of state-led innovation system. The government preferred the involvement of state-owned companies within the system. Besides private companies were considered to having a low capacity in both financial and human resources, state-owned companies were the "cash cow" of country's revenue at that time.

Third, the government implemented the "one door policy" for program and budget mechanism as another source of legitimacy. Ristek organized the entire R\&D budget for all PRIs, including research units under line ministries. The close relationship between BPPT and Ristek was beneficial for engineers in BPPT to succeed in program planning and implementation, including the highest budget among all PRIs.

The Asian financial crisis in 1997 had a huge impact on socio-economic and political transformation in Indonesia. The crisis was aggravated by the regime change. The downfall of the authoritarian regime in 1998 led to reformation in many sectors. The central government no longer plays the key role in state building. Economic development strategy has turned from being state-led to being neoliberal. This condition has affected the other sectors as well, including S\&T development. In this condition, particularly after the government got the International Monetary Fund (IMF) austerity, all financial supports for IPTN (Nusantara Aircraft Industry) were stopped. The fall of the New Order at the same time ended the technological state era. It resulted not only in the termination of the aircraft industry, which had brought up the State's pride, but also in the abolishment of BPIS during the transition era to erase any legacy of the New Order.

After the Asian financial crisis (1998-present), the new country's condition led the government to change its strategy on S\&T development. After the transition era (1998-2004), the Yudhoyono administration (20042014) used S\&T as a means of strengthening national competitiveness. The goal of the Indonesia's 2005-2025 Long Term National Development Plan (RPJP) is to create an independent, developed, just, and prosperous nation. The third of the five missions to accomplish this vision is the acquisition and utilization of S\&T. The importance of $\mathrm{S} \& \mathrm{~T}$ development for improving competitiveness is restated in the Masterplan for Acceleration and Expansion of Indonesia Economic Development (MP3EI), 2011-2025. 
There are two main strategies to attain the goals of S\&T development. The first is to strengthen the national innovation system in the area of production, process, and commercialization to improve competitiveness towards an innovation-driven economy. The second is to enhance the capacity for research, development, and application of S\&T, especially in seven fields: food security, energy security, information technology and communication (ICT), transportation technology and management, defense and security technology, pharmaceutical and health, and advanced materials. R\&D activities in these seven fields are interrelated and conducted by strengthening basic research and considering the impact on the social dimension.

Although S\&T development has a seemingly high priority in the current development plan, the policy implementation is weak. The government promotes a national innovation system but sets no priority to harness any specific sector in certain years before moving to other sectors. Currently, R\&D activity also faces a reduction in funding support.

The government no longer employs the "one door policy" mechanism as a policy instrument to formulate $\mathrm{R} \& \mathrm{D}$ programs and budget. In order to realize a strong innovation system, the government gives equal opportunity to all sectors and research areas to develop. There are no privileges for any particular agency, nor is there a strong figure with high authority. Ristek still coordinates S\&T development in Indonesia, whose R\&D activity is conducted in several research institutes. However, this coordination is merely administrative, particularly in the case of the broad S\&T policy and R\&D agenda. Each PRI has freedom to prepare a program and propose a budget for approval from the House of Representatives (DPR).

\subsection{Transformational role of LIPI}

LIPI is the biggest and oldest research institute in Indonesia. It has a long history in the development of Indonesian scientific research. The first colonial research institute's lands Plantentuin te Buitenzorg (National Botanical Garden in Bogor), founded in 1817, has become one of the research units of LIPI for conducting life science research and ex situ conservation.

The inception of LIPI dates back to 1956, when the government established MIPI. MIPI acted as an advisory council for the government and was responsible for the development and dissemination of science. The government founded National Research Institute (Lemrenas) in 1966 and put MIPI within the organization by adding the task of establishing and nurturing several research institutes. In 1967, the New Order government abolished MIPI and Lemrenas and established LIPI to take over all missions of the previous institutions.

In the early days of its inception, LIPI aimed to guide the development of science in Indonesia, to conduct scientific research, and to prepare the inception of the Indonesian Academy of Science. This last mission was handled by Ristek in 1991. Growing out of life sciences research and an advisory council, the institute is responsible for conducting multidisciplinary research in the area of life sciences, humanities, engineering sciences, earth sciences and for providing scientific services of standard measurements and calibration. The New Order government set up a division of labor to avoid an overlap in tasks with BPPT, because both institutes conducted multidisciplinary research. Hence, LIPI conducted basic research up to the intermediate stage of knowledge production. On the other hand, BPPT conducted applied research and development on the downstream side.

Since its establishment in 1967, LIPI has undergone some organizational changes and an adjustment of its main tasks. The latest regulation on the LIPI is the Presidential Decree No. 103 of 2001. It mentions that the role of LIPI is to formulate policy on scientific research and to conduct basic research. However, the postauthoritarian government has used a different strategy on Indonesian S\&T development. The government intends to develop the national innovation system and expects direct contribution from the research sector to social and economic benefit. This strategy has opened more opportunities for LIPI to expand its role, including conducting applied research and development. The current missions of LIPI have shifted somewhat.

It aims (1) to create scientific inventions to encourage innovation in order to improve the competitiveness of national economies, (2) to develop useful knowledge for the conservation and sustainable utilization of natural resources (such as research on biotechnology for agricultural production, medicine, etc.), (3) to increase international recognition in the field of science, and (4) to improve the quality of Indonesian human resources through scientific activity (LIPI, 2016).

The institute established the Innovation Centre in 2001 to manage intellectual property rights and to get closer with industry so as to be able to transfer the research output there. Some of LIPI's products in late 2014 are electric vehicles (bus and car), the Indonesian sea radar, an organic fertilizer, and so forth. Nonetheless, LIPI finds that it is not easy when coming to commercialization stage. There have been around 360 registered patents since 2001, but not more than $10 \%$ of them have been commercialized (Center for Innovation, 2015).

LIPI also built an incubator in 2013 to link research institutes, the industry, and the community. LIPI can provide promotional, business-related, and technological assistance for start-ups in the incubator. At the same 
time, tenants can learn and license LIPI's technology to support their business. But it is still hard. In the last two years, there are only 10 tenants in LIPI's incubator (LIPI, 2016).

On the other hand, LIPI could be more successful by involving community participation for utilizing the research results. Societies are usually involved in implementing new products and processes, which closely relates to indigenous resources. For example, LIPI disseminates some agricultural techniques and fertilizers to improve agricultural products, such as avocado, banana, rice, and so on (LIPI, 2016).

\subsection{Transformational role of BPPT}

BPPT was founded as a mission-oriented body. BPPT now conducts multidisciplinary research and development. The research fields comprise technology policy assessment, natural resources development technology, agro-industrial technology and biotechnology, information, energy, and material technology, and design and engineering industrial technology. The inception of BPPT dates back to the New Order era, when the government attempted to develop highly indigenous technology.

Initially, the government established the Advanced Technology and Aeronautical Technology (ATTP), a special division in Pertamina, in 1974. This division aimed to provide a space for Habibie and his Germanyeducated engineers to prepare an aircraft manufacturer. Within two years, ATTP was transformed into the Advanced Technology Pertamina (ATP). This transformation gave ATP broader tasks, as the mission was no longer limited to preparing an aircraft industry, which IPTN took over.

The mission of ATP was to prepare the inception of a technological bureaucracy. ATP became an instrument through which Habibie could organize the new concept of technological development. ATP had four interrelated tasks. First, it would prepare an industrial development policy together with the Ministry of Industry, after the country's high reliance on agricultural economy in 1970s. Second, it would conduct operations research, using mathematical formulation for technology-based decisionmaking and system design. Third, the engineers would harness Indonesia's natural resources endowment through technological development. It aimed to develop the indigenous technological capacity of Pertamina as the only state-owned oil company to reduce dependency on imported technology for the extraction of natural resources. The last task was to improve technological capacity through education and training. Eventually, ATP grew to become the highest funded government agency, drawing resources from the oil revenue. This condition led to jealousy from other government departments, especially Bappenas, which had been the most powerful agency in the cabinet earlier (Amir, 2013).
By using a presidential decree, the New Order government officially established BPPT in 1978 as a nonministry governmental agency of the same status as LIPI. BPPT was an unprecedented non-ministerial institute due to the figure of Habibie. The one door policy for the program and budget mechanism under Ristek was not a problem, since the same person headed them. BPPT has more authority in the assessment and application of technology in both public and private sectors.

BPPT also gained the highest budget allocation among government research institutes. The extraordinary funding it received for its high-technology projects became subject to debate because of the imbalance in fund distribution. In 1991-1992, part of the fifth period of New Order regime (Repelita V, 1989- 1994), BPPT shared the highest budget allocation (60\%) among six PRIs. In second position was Batan (12\%) and the rest, including LIPI, received less than $10 \%$ of the budget allocation (Hill, 1995). This disaggregation of budget allocation reflected the political and strategic importance of the ruling regime.

BPPT also had great influence on state-owned strategic industries. It was in charge not only of preparing the technological policy, but also of its implementation in all sectors. Due to its authority, some critics argued that BPPT was comparable to Bappenas, which was steered by Western-trained technocrats (Amir, 2013).

Nevertheless, the overthrow of the authoritarian New Order in 1998 following the 1997 Asian Financial Crisis significantly affected S\&T policy and institution. Especially after the end of Habibie's government, BPPT lost its power and authority on policymaking in many strategic sectors. Post-authoritarian era, the government gives equal opportunity to all research areas to develop. The government does not give priority to particular sector. There is no strong figure anymore, not only at the ministry level, but also on LPNK.

The main functions of BPPT have remained the same. It conducts multidisciplinary research for development of technology. The assessment and application of technology are currently not limited in the high technology industry. It reaches the fields of agroindustry technology and biotechnology, information technology, energy and material, design and engineering, and the technological development of natural resources (BPPT, 2016).

However, there is a significant change in BPPT's role in terms of its targeted market. BPPT had a strong connection to state-owned industries in the New Order era. They were the target of BPPT's technology development through BPIS. But the post-authoritarian government would like to strengthen the country's competitiveness, in which firms are the main actors, not 
only state-owned companies but also private companies. BPPT currently faces difficulties in reaching these private firms for either technology transfer or collaboration. Private firms prefer ready-to-use, mainly imported technologies rather than producing the new ones. Transnational companies also rely more on the technology produced in their home countries. Furthermore, many firms complain that research institutes such as BPPT or LIPI, fail to understand the need of companies.

\section{Discussion}

The government has played an important role in the development of S\&T in Indonesia. The country has witnessed several transformations in the politicoeconomic structure in its history. This transformation has affected the institutional development of Indonesian S\&T, which in turn influences the role of LIPI and BPPT that play an important role in national innovation system.

The early colonial era encouraged research culture in Indonesia through medical and agricultural research by exploring Indonesian bio-resources. In the next phase, as a newly independent country, the State was preoccupied with the consolidation of the nation. Yet, in this era, the Old Order (1945-1966) government laid the institutional base for S\&T development by establishing a research council to give the government scientific advice.

The New Order (1966-1998) government faced different challenges and offered different strategies for S\&T development. S\&T development in this regime had a lot of influence through Habibie. The government created an authoritarian technological state by imposing the development of highly indigenous technology. Priority was given to favored agents could support the State's goal. Thus, BPPT was established as a missionoriented agency to prepare and implement industrial technology policy with state-owned strategic industries as their targeted market, especially the aircraft industry. On the other hand, the government paid less attention to other research institutes, such as LIPI, which conducted basic research despite its long history and achievements in life sciences.

The downfall of the New Order following the 1997 Asian Financial Crisis might have led to another transformation in S\&T development strategy. The government now gives an equal opportunity for all research areas and institutes to develop in order to strengthen the national innovation system. This changing strategy might have affected the transformational role of LIPI and BPPT too. LIPI has expanded its role to include not merely basic research, but also applied research and development. BPPT maintains its function of technology assessment and application, but has decreasing authority following the end of Habibie era.

However, the two institutions are seemingly not ready to face the rapid growth of private companies, since stateowned companies were the only partners for technology development in the previous era. BPPT finds difficulty to reach out to the private sector for technological service; it is not as easy as to link to a state-owned company. Similarly, LIPI also faces challenges in commercializing its research results. Nonetheless, it is successful when LIPI involves the society for a transfer of research results, particularly in the area of indigenous resources production. This condition has not been created by accident, if we consider the long history of life science research from which LIPI has grown. Medical and agricultural research based on natural resources have long been rooted in LIPI's history. It continues as LIPI plays an important role in the exploration of Indonesian biodiversity at present.

\section{Conclusion}

Political transformation has much influenced the government's strategy for S\&T development in Indonesia. This strategy might eventually have affected the transformational role of LIPI and BPPT. Nonetheless, LIPI and BPPT give less consideration to the changing social and economic demands of society and the industry.

Therefore, the government should consider a more appropriate strategy for S\&T development to face today's challenges. S\&T development in Indonesia needs a clear division of labor. Currently, domestic private companies prefer to use imported technology rather than producing their own due to high cost and risk. At this stage, BPPT might be the better institution to act as an intermediary to improve the technological capacity of local firms through learning and adoption of existing technology before being ready to produce new technology, particularly through networking with transnational companies. It is in line with the stages of technological development as introduced by Habibie earlier. On the other hand, LIPI might function best by enhancing its capacity for research in the life sciences and social sciences. Indonesian biodiversity has a large potential for exploration. Each area has its unique local wisdom to contribute directly to the local people, not only for food but also for medical use.

\section{References}

Agency for the assessment and application of technology (BPPT). (2016). The 2015 BPPT's Annual Report. Jakarta: BPPT. 
Amir, S. (2013). The technological state in Indonesia: The co-constitution of high technology and authoritarian politics. London: Routledge.

Bimantara, J. (2015, December 11). Kompas Daily. Retrieved

from: http://print.kompas.com/baca/2015/12/11/Kebut uhan-Industri-Bertemu-Tawaran-Riset

Boomgaard, P. (1993). The development of colonial health care in Java: An exploratory introduction. Bijdragen tot de Taal-, Land- en Volkenkunde 149(1), 77-93.

Boomgaard, P. (2006). The making and unmaking of tropical science: Dutch research on Indonesia, 1600-2000. Bijdragen tot de Taal-, Land-en Volkenkunde, 162(2/3), 191-217.

Cabinet Secretary. (2010). Presidential Decree No. 5 of 2010 on The Mid-Term National Development Planning 2010-2014.

Center for Innovation. (2015, February 03). Retrieved from http://www.inovasi.lipi.go.id/en/news/penguata n-jejaring-kegiatan-diseminasi-dan-alih-ilmupengetahuan-dan-teknologi-lipi

Edquist, C. (2004). System of innovation: Perspectives and challenges. In J. Fagerberg, D. C. Mowery, $\&$ R. Nelson, The Oxford handbook of innovation (p. 183). London: Oxford University Pess.

Hill, H. (1994). The Economy. In H. Hill, Indonesia's New Order (pp. 54-114). New South Wales: Allen \& Unwin Pty Ltd.

Hill, H. (1995). Indonesia's great leap forward? Technology development and policy issues. Bulletin of Indonesian Economic Studies, 31(2), 83-123.

Hill, H. (1997). Indonesia's industrial transformation. Singapore: Institute of Southeast Asian Studies.
Intarakumnerd, P., \& Goto, A. (2016). Role of public research institutes in national innovation systems in industrialized countries: The cases of Fraunhofer, NIST, CSIRO, AIST, and ITRI. RIETI Discussion Paper Series 16-E-041.

LIPI. (2016). Laporan kinerja instansi pemerintah LIPI Tahun 2015 [LIPI's annual report 2015]. Jakarta: LIPI.

OECD. (2013). Indonesian innovation profile: Part of OECD reviews of innovation policy innovation in Southeast Asia. Retrieved from http://dx.doi.org/10.1787/9789264128712-en

Pitono, D. (1996). The development of strategic industries in Indonesia. In L. Hakim, Industrial and technology policy for economic development in Indonesia (pp. 96-107). Jakarta: Pappiptek LIPI.

Pyenson, L. (1989). Empire of Reason: Exact sciences in Indonesia, 1840-1940. Leiden: E.J. Brill.

Reid, Anthony. (2015). A History of Southeast Asia: Critical Crossroads, Chichester: Wiley Blackwell.

Rice, R. C. (1998). The Habibie approach to science, technology, and national development. In H. Hill, \& K. W. Thee, Indonesia's technological challenge (pp. 185-198). Singapore: Institute of Southeast Asian Studies.

Ricklefs, M C, Bruce Lockhart, Albert Lau, Portia Reyes and Maitrii Aung-Thwin. (2010). A new history of South East Asia, Basingstoke: Palgrave Macmillan

Sato, Y. (2017). State, Industry, and Business in Indonesia's Transformation. In B. Khoo, K. Tsunekawa, \& M. Kawano, Southeast Asia beyond Crises and Traps: Economic Growth and Upgrading (pp. 71-99). London: Palgrave Macmillan (about to being published). 